\title{
WHO antibody reference panel for donor screening assays that detect antibodies to human T-lymphotropic virus type 1 (HTLV-1) and type 2 (HTLV-2)
}

\author{
Erin Wigglesworth ${ }^{1 *}$, Elliot P Cowan², Clare Morris ${ }^{1}$ \\ From 15th International Conference on Human Retroviruses: HTLV and Related Viruses \\ Leuven and Gembloux, Belgium. 5-8 June 2011
}

Antibody screening tests are critical tools to identify individuals infected with HTLV-1 and HTLV-2. However, the lack of reference panels hinders the ability to evaluate existing tests and new technologies that aid in the screening for these agents. For example, some HTLV-2 subtypes may escape detection by currently available technology. The World Health Organization, through the support of the WHO Expert Committee on Biological Standardization, is in the process of generating such a reference panel.

This reference panel will best function as a tool for test assessment only if it consists of specimens representing the diversity of HTLV-1 and HTLV-2, especially those subtypes known to present challenges to detection using serological tests. A panel consisting of seven members (HTLV-1a-d and HTLV-2a,b,d) is being considered.

The reference panel will be fully characterised and assessed in an international collaborative study. This first WHO HTLV antibody reference panel is expected to be used by blood screening and diagnostic test developers, blood banks, hospitals and other establishments performing HTLV serology testing.

\section{Author details}

'Division of Retrovirology, NIBSC, Potters Bar, Hertfordshire, EN6 3QG, UK. ${ }^{2}$ Division of Emerging and Transfusion Transmitted Diseases, Center for Biologics Evaluation and Research, US FDA, Rockville, Maryland, 20852, USA.

Published: 6 June 2011

\footnotetext{
* Correspondence: Erin.Wigglesworth@nibsc.hpa.org.uk

'Division of Retrovirology, NIBSC, Potters Bar, Hertfordshire, EN6 3QG, UK

Full list of author information is available at the end of the article
}

doi:10.1186/1742-4690-8-S1-A246

Cite this article as: Wigglesworth et al:: WHO antibody reference panel for donor screening assays that detect antibodies to human Tlymphotropic virus type 1 (HTLV-1) and type 2 (HTLV-2). Retrovirology 2011 8(Suppl 1):A246.
Submit your next manuscript to BioMed Central and take full advantage of:

- Convenient online submission

- Thorough peer review

- No space constraints or color figure charges

- Immediate publication on acceptance

- Inclusion in PubMed, CAS, Scopus and Google Scholar

- Research which is freely available for redistribution
C Biomed Central 